\title{
How can the European ceramic tile industry meet the EU's low-carbon targets? A life cycle perspective
}

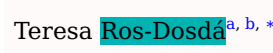

teresa.ros@itc.uji.es

\section{Pere Fullana-i-Palmer}

Paolo

Eliseo Monfort

aInstituto de Tecnología Cerámica (ITC), Asociación de Investigación de las Industrias Cerámicas (AICE), Universidad Jaume I, Avda. Sos Baynat s/n, 12006, Castellón, Spain

bUNESCO Chair in Life Cycle and Climate Change (ESCI-UPF), Passeig Pujades 1, 08003 Barcelona, Spain

'Italian National Agency for New Technologies, Energy and Sustainable Economic Development (ENEA), Via Martiri di Monte Sole 4, 40129 Bologna, Italy

${ }^{*}$ Corresponding author. Instituto de Tecnología Cerámica (ITC), Asociación de Investigación de las Industrias Cerámicas (AICE), Universidad Jaume I, Avda. Sos Baynat s/n, 12006, Castellón, Spain.

${ }^{\mathbf{1}}$ Presently, Ecoinnovazione srl; via D'Azeglio 52, 40123 Bologna, Italy.

\section{Abstract}

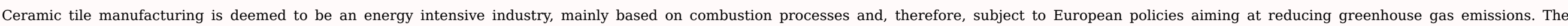

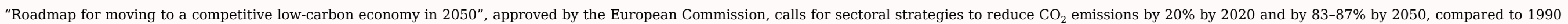

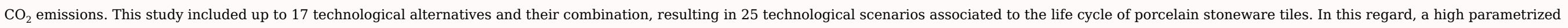

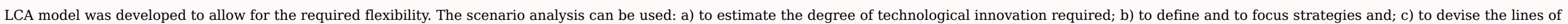

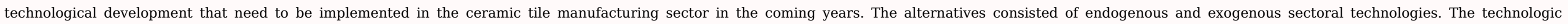

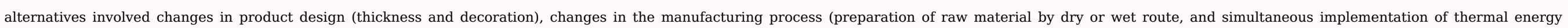

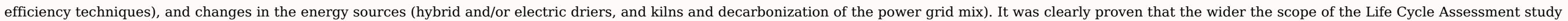

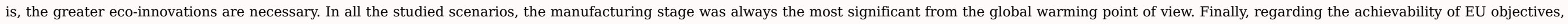

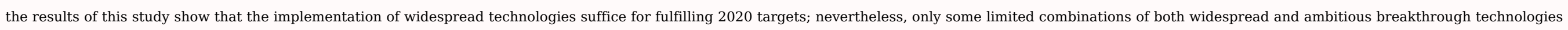
may achieve the 2050 reduction targets.

Keywords: Low-carbon economy; Ceramic tiles; Life cycle assessment; Technological scenarios

\section{Introduction}

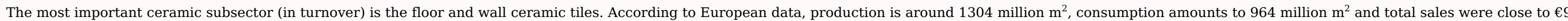

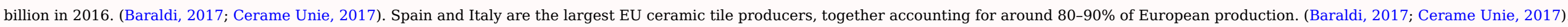

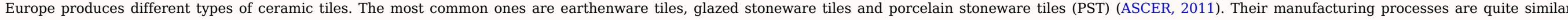

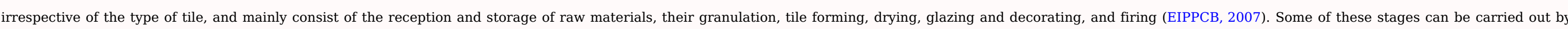




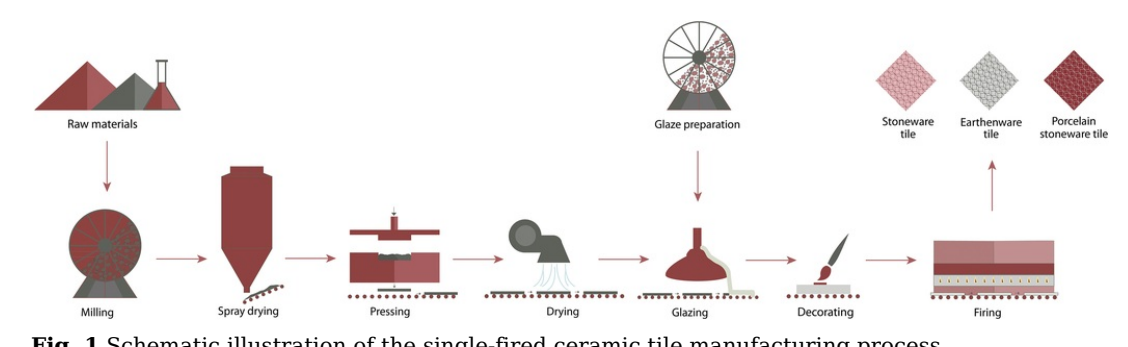

Fig. 1 Schematic illustration of the single-fired ceramic tile manufacturing process.

\section{alt-text: Fig. 1}

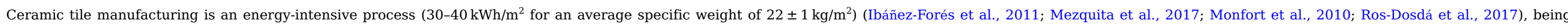

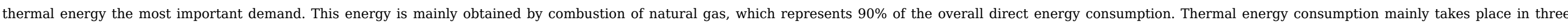
process stages: spray drying of ceramic slurries (36\%), drying of the formed ceramic tile bodies (9\%), and ceramic tile firing (55\%) (EIPPCB, 2007; Monfort et al., 2010).

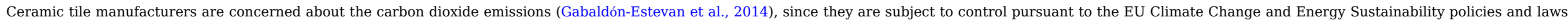

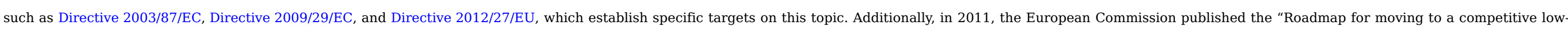
carbon economy in 2050" and, for the industrial sectors, the objective is to reduce $\mathrm{CO}_{2}$ emissions from 83\% to 87\% by 2050 (COM (2011) 112 final).

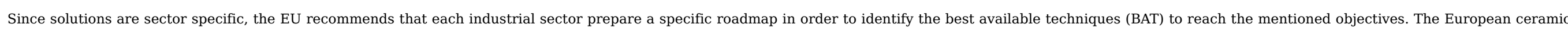

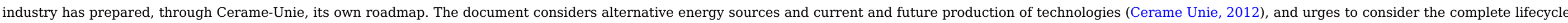
of ceramics, arguing that the contribution of durable products to resource and energy efficiency can only be appreciated with a holistic approach, including its durability and impact over the use phase.

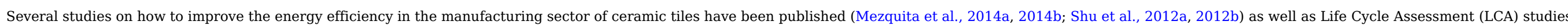
that identify hotspots and make proposals for improvement (Almeida et al., 2016; Bovea et al., 2010; Ibáñez-Forés et al., 2013).

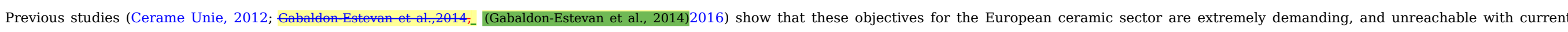

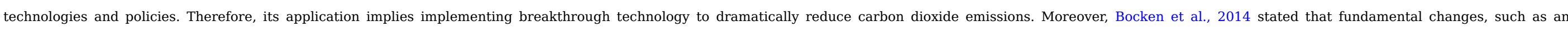

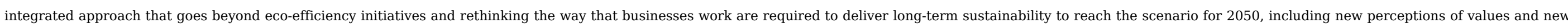
business models aligned in a route to a sustainable and circular economy.

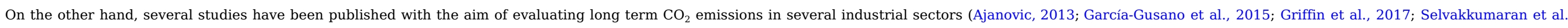

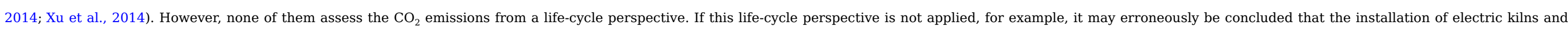

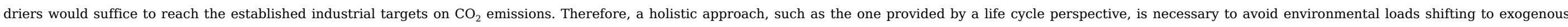

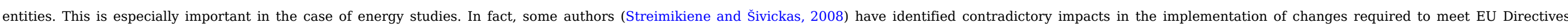

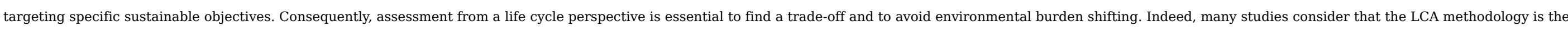

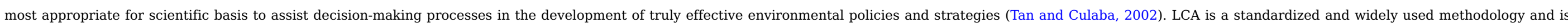
accepted for analyzing the interactions of a technological system with the environment (Guinée et al., 2002; Klöpffer and Grahl, 2009; Tan and Culaba, 2002).

In this regard, the aim of this study is to compare different technological options to reach the EU 2020 and 2050 Greenhouse Gas (GHG) emissions objectives, applying an attributional LCA approach.

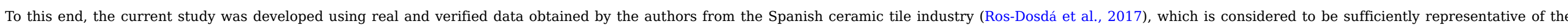

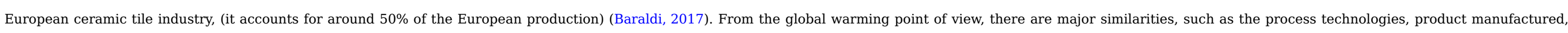




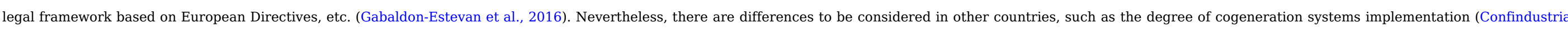

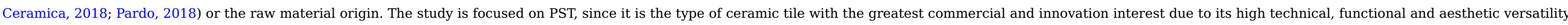
(ASCER, 2011; Sánchez et al., 2010).

\section{Research method}

\subsection{Goal definition}

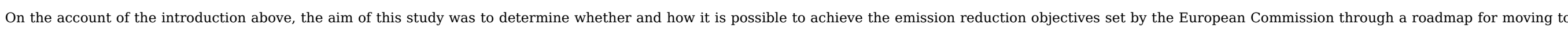
(and surviving in) a competitive low carbon economy in 2020 and 2050, using the LCA methodology on different technological scenarios of the PST life cycle.

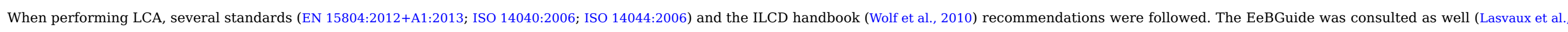

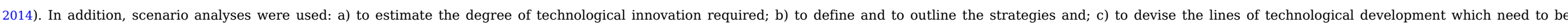
implemented in the ceramic tile manufacturing sector in the coming years.

\subsection{System definition and functional unit}

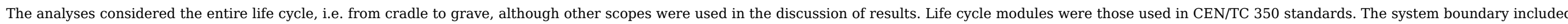

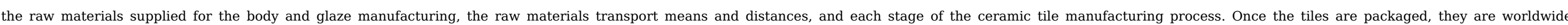

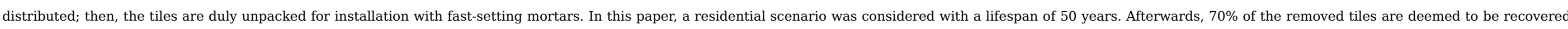
as a filler, and $30 \%$ landfilled.

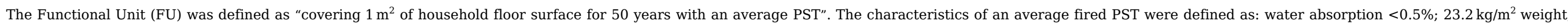
and $10.4 \mathrm{~mm}$ thickness with $0.76 \mathrm{~kg} / \mathrm{m}^{2}$ of glazes (Ros-Dosdá et al., 2017).

\subsection{Baseline scenario and latest scenario}

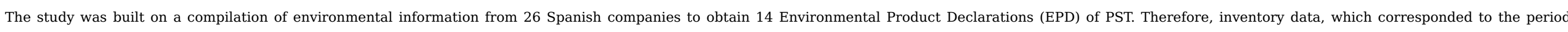

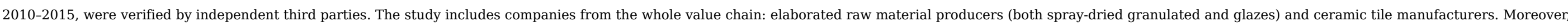
some generic data, such as the type of means of transport or the type of waste management processes, were taken from a Spanish sectoral LCA study, carried out in 2007-2009 (Ros-Dosdá et al., 2017).

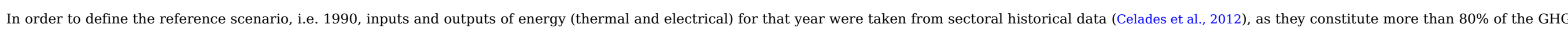

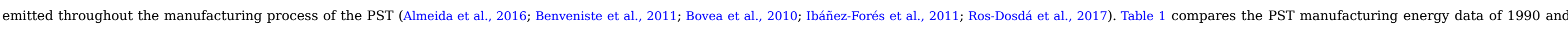
$2010-2015$.

Table 1 Main changes in the energy data inventory from 1990 to 2010-15.

alt-text: Table 1

\section{INPUTS}

Electrical energy taken from the grid $\left(\mathrm{MJ} / \mathrm{m}^{2}\right)$ 
${ }^{\mathbf{a}}$ Including natural gas to feed the combined heat and power cogeneration system (CS) installed in the spray drier.

\subsection{Limitations}

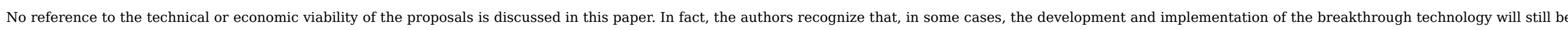

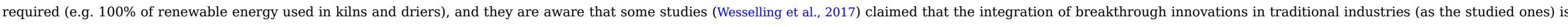

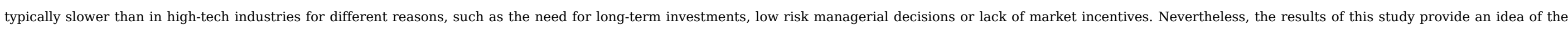
level of theoretical demand set by the European Union and the technological trends to fulfil the required targets.

\subsection{Selection of environmental impact categories}

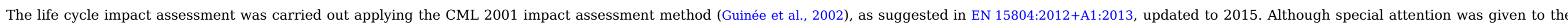
Global Warming Potential (GWP), other environmental categories were also analyzed under the CML 2001 method (Guinée et al., 2002), as shown in Table 2, to study potential environmental burden shifting.

\section{Table 2 Environmental impact categories.}

\section{alt-text: Table 2}

Abiotic Depletion - elements

Abiotic Depletion - fossil fuels

Acidification Potential

Eutrophication Potential

Global Warming Potential (100 years)

Ozone Layer Depletion Potential (steady state)

Photochemical Ozone Creation Potential
Impact category

\subsection{LCA model}

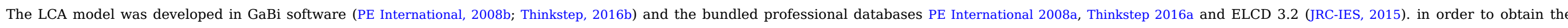

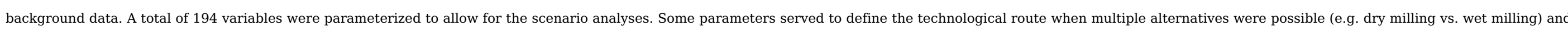

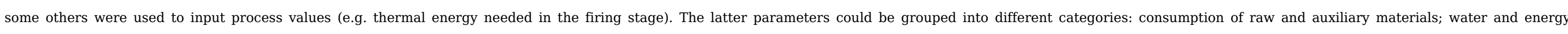

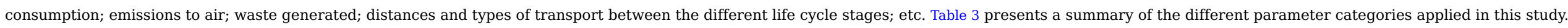

Table 3 (For a better reading, replace this table with the attached one)Parameters included in the LCA model.

alt-text: Table 3

Parameters to define the technological route

Processes

Technological route

a) Wet milling

b) Dry milling

\section{Features}

It is possible to define an application rate for each route kg Sb Equivalent

MJ

$\mathrm{kg} \mathrm{SO} \mathrm{S}_{2}$ Equivalent

$\mathrm{kg} \mathrm{PO}_{4}{ }^{3-}$ Equivalent

$\mathrm{kg} \mathrm{CO}$ Equivalent

kg R11 Equivalent

$\mathrm{kg} \mathrm{C}_{2} \mathrm{H}_{4}$ Equivalent
Body raw materials preparation 


\begin{tabular}{|c|c|c|}
\hline Forming & $\begin{array}{l}\text { a) Pressing } \\
\text { b) Extrusion }\end{array}$ & \\
\hline Waste management & $\begin{array}{l}\text { a) Incineration } \\
\text { b) Recycling } \\
\text { c) Disposal }\end{array}$ & \\
\hline Firing & $\begin{array}{l}\text { a) Single firing } \\
\text { b) Double firing }\end{array}$ & One of the possible routes must be chosen \\
\hline Use scenario & $\begin{array}{l}\text { a) Residential use } \\
\text { b) Commercial use } \\
\text { c) Sanitary use }\end{array}$ & \\
\hline \multicolumn{3}{|c|}{ Parameters to define the process values (quantification of inputs/outputs) } \\
\hline Type of parameters & Life cycle processes & Features \\
\hline Types and quantities of raw materials & $\begin{array}{l}\text { - Body composition } \\
\text { - Glaze composition }\end{array}$ & Mineralogical composition \\
\hline Types and distances in transports & $\begin{array}{l}\text { - Raw materials to the granulates factory } \\
\text { - Granulates to the tile factory } \\
\text { - Glazes to the tile factory } \\
\text { - Packaging to the tile factory and to the glazes factory } \\
\text { - Auxiliary materials: } \\
\text { - to the tile factory } \\
\text { - to the installation site } \\
\text { - to the building } \\
\text { - Tiles to the buildings }\end{array}$ & Type of vehicle (truck, trailer, cargo), load capacity \\
\hline
\end{tabular}




\begin{tabular}{|c|c|c|}
\hline Energy consumption & $\begin{array}{l}\text { - Granulate production } \\
\text { - Glaze production } \\
\text { - Tile production }\end{array}$ & Thermal and electrical energy \\
\hline Water consumption & $\begin{array}{l}\text { - Granulate production } \\
\text { - Glaze production } \\
\text { - Tile production } \\
\text { - Tile installation }\end{array}$ & Source of water: tap water; groundwater; recycled water \\
\hline Quantity and type of emissions to the air & $\begin{array}{l}\text { - Granulate production } \\
\text { - Glaze production } \\
\text { - Tile production }\end{array}$ & Channeled emissions (cold and hot) \\
\hline Quantity and quality of waste water & $\begin{array}{l}\text { - Granulate production } \\
\text { - Glaze production } \\
\text { - Tile production }\end{array}$ & Destination, pollutants and management processes \\
\hline Solid waste & $\begin{array}{l}\text { - Granulate production } \\
\text { - Glaze production } \\
\text { - Tile production } \\
\text { - Tile installation } \\
\text { - Tile maintenance } \\
\text { - End-of-life }\end{array}$ & $\begin{array}{l}\text { Hazardous and non-hazardous wastes } \\
\text { Destination and management processes }\end{array}$ \\
\hline
\end{tabular}

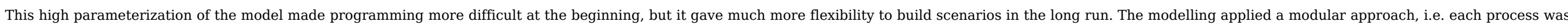
modelled separately to facilitate the definition of process routes and technological and managerial options, providing high flexibility in the scenario simulation process.

\subsection{Technological alternatives}

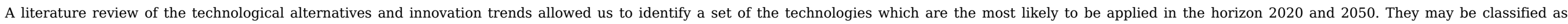

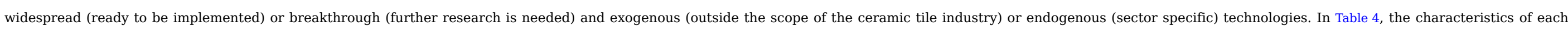
technological alternative are summarized, as well as the reference source used to identify these technological alternatives and their representative values for energy and material. 


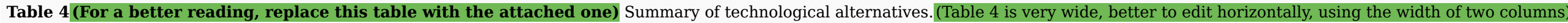

\begin{tabular}{|c|c|c|c|c|}
\hline \multirow{2}{*}{\multicolumn{2}{|c|}{ Technological alternatives }} & \multicolumn{2}{|r|}{ Options } & \multirow[t]{2}{*}{ References sources } \\
\hline & & Reference & Description & \\
\hline \multirow[t]{5}{*}{ Product design } & \multirow[t]{3}{*}{ Quantity of glaze } & GL100 & $\begin{array}{l}\text { Current average amount of glaze decorative materials. For PST is } \\
\text { estimated as } 0.76 \mathrm{~kg} / \mathrm{m}^{2} \text { solid, with } 33 \% \text { frit content }\end{array}$ & \multirow[t]{3}{*}{ ASCER 2011; Nicoletti et al., 2002; Ros Dosdá et al., 2017} \\
\hline & & GL50 & Reduction in the amount of glaze in $50 \%$ & \\
\hline & & GL0 & No glaze coating or decoration is applied & \\
\hline & \multirow[t]{2}{*}{ Thickness of the tile } & TH100 & Current PST average thickness. $10.4 \mathrm{~mm}$, weighing $24.2 \mathrm{~kg} / \mathrm{m}^{2}$ unfired & \multirow{2}{*}{$\begin{array}{l}\text { ASCER 2011; Da Silva et al., 2014a, 2014b; Girao et al., 2009; Pini et al., } \\
\text { 2014; Raimondo, 2010; Ros Dosdá et al., } 2017\end{array}$} \\
\hline & & TH50 & Reduction of $50 \%$ of PST thickness, thus reducing its mass. & \\
\hline \multirow{4}{*}{$\begin{array}{l}\text { Manufacturing } \\
\text { process }\end{array}$} & \multirow{2}{*}{$\begin{array}{l}\text { Body raw material preparation } \\
\text { process }\end{array}$} & WCS & Wet milling of body raw materials using cogeneration systems & \multirow{2}{*}{$\begin{array}{l}\text { Mezquita et al., 2017; Bonucchi, 2012; Melchiades et al., 2010; Schianchi, } \\
\text { 2012; Shu et al., 2012a, 2012b }\end{array}$} \\
\hline & & DRY & Dry milling of body raw materials & \\
\hline & \multirow{2}{*}{$\begin{array}{l}\text { Energy efficiency technologies } \\
\text { in driers and kilns }\end{array}$} & СТT & Current Thermal Technology scenario in driers and kilns & \multirow{2}{*}{$\begin{array}{l}\text { Almeida et al., 2016; Bovea et al., 2010; Ibáñez-Forés et al., 2013; } \\
\text { Mezquita et al., 2014a, 2014b }\end{array}$} \\
\hline & & WDS & $\begin{array}{l}\text { Simultaneous implementation of widespread technologies to increase the } \\
\text { overall efficiency up to } 45 \% \text { (driers + kilns) }\end{array}$ & \\
\hline \multirow[t]{5}{*}{$\begin{array}{l}\text { Energy } \\
\text { sources }\end{array}$} & \multirow[t]{2}{*}{ Electric energy source } & $\begin{array}{l}\text { SGM90 } \\
\text { SGM15 } \\
\text { SGM20 } \\
\text { SGM50 }\end{array}$ & $\begin{array}{l}\text { Electricity from the Spanish Power Grid Mix (SGM) of different years } \\
(1990,2015,2020,2050)\end{array}$ & \multirow[t]{2}{*}{$\begin{array}{l}\text { Cerame Unie 2012; Capros et al., 2013; Gabaldón-Estevan et al., 2014, } \\
\text { 2016; REE, } 2016\end{array}$} \\
\hline & & REN50 & Electricity in 2050 came from a mix of $100 \%$ renewable sources & \\
\hline & \multirow[t]{3}{*}{ Thermal energy source } & NG100 & Combustion: $100 \%$ natural gas & \multirow[t]{3}{*}{ Cerame Unie 2012; Ros Dosdá et al., 2017} \\
\hline & & NG50 & Hybrid: $50 \%$ natural gas $+50 \%$ electric sources & \\
\hline & & NG0 & Electric: $100 \%$ electric sources & \\
\hline
\end{tabular}

A sensitivity analysis was carried out to identify the most critical parameters from the point of view of global warming. This material is attached as supplementary information.

\subsection{Technological scenarios}

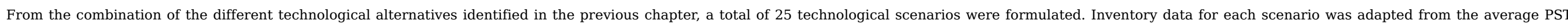
inventory (Ros-Dosdá et al., 2017) to the technological alternatives applied in each case.

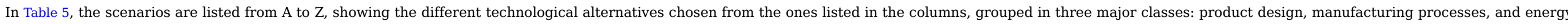

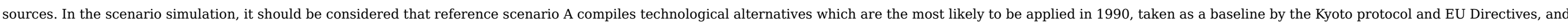
scenario C represents the most likely technological situation in the ceramic tile industry in 2015.

Table 5 (For a better reading, replace this table with the attached one)Simulated technological scenarios (made up of a combination of technological alternatives).

alt-text: Table 5

Scenarios

Technological Alternatives

Product design

Manufacturing processes

Energy sources

Glaze

Thickness

Milling

Driers \& Kilns

Electric energy source

Thermal energy source 


\begin{tabular}{|c|c|c|c|c|c|c|c|c|c|c|c|c|c|c|c|c|c|}
\hline & GL100 & GL50 & GL0 & TH100 & TH50 & WCS & DRY & СТT & WDS & SGM90 & SGM15 & SGM20 & SGM50 & REN50 & NG100 & NG50 & NG0 \\
\hline A (baseline) & $\mathrm{X}$ & & & $\mathrm{X}$ & & $\mathrm{X}$ & & $\mathrm{X}$ & & $\mathrm{X}$ & & & & & $\mathrm{X}$ & & \\
\hline C (2015) & $\mathrm{X}$ & & & $\mathrm{X}$ & & $\mathrm{X}$ & & $\mathrm{X}$ & & & $\mathrm{X}$ & & & & $\mathrm{X}$ & & \\
\hline $\mathrm{D}$ & $\mathrm{X}$ & & & $\mathrm{X}$ & & $\mathrm{X}$ & & & $\mathrm{X}$ & & $\mathrm{X}$ & & & & $\mathrm{X}$ & & \\
\hline E & $\mathrm{X}$ & & & $\mathrm{X}$ & & $\mathrm{X}$ & & & $\mathrm{X}$ & & & $\mathrm{X}$ & & & $\mathrm{X}$ & & \\
\hline $\mathrm{F}$ & $\mathrm{X}$ & & & $\mathrm{X}$ & & $\mathrm{x}$ & & & $\mathrm{X}$ & & & & $\mathrm{x}$ & & $\mathrm{X}$ & & \\
\hline G & $\mathrm{X}$ & & & $\mathrm{X}$ & & & $\mathrm{X}$ & & $\mathrm{X}$ & & & $\mathrm{X}$ & & & $\mathrm{X}$ & & \\
\hline $\mathrm{H}$ & $\mathrm{X}$ & & & $\mathrm{X}$ & & & $\mathrm{X}$ & & $\mathrm{X}$ & & & & $\mathrm{X}$ & & $\mathrm{X}$ & & \\
\hline I & $\mathrm{X}$ & & & $\mathrm{X}$ & & $\mathrm{X}$ & & & $\mathrm{X}$ & & & $\mathrm{X}$ & & & & $\mathrm{X}$ & \\
\hline $\mathrm{J}$ & $\mathrm{X}$ & & & $\mathrm{X}$ & & $\mathrm{X}$ & & & $\mathrm{X}$ & & & & $\mathrm{X}$ & & & $\mathrm{X}$ & \\
\hline K & $\mathrm{X}$ & & & $\mathrm{X}$ & & & $\mathrm{x}$ & & $\mathrm{x}$ & & & $\mathrm{X}$ & & & & $\mathrm{X}$ & \\
\hline $\mathrm{L}$ & $\mathrm{X}$ & & & $\mathrm{X}$ & & & $\mathrm{X}$ & & $\mathrm{X}$ & & & & $\mathrm{X}$ & & & $\mathrm{X}$ & \\
\hline $\mathrm{M}$ & $\mathrm{X}$ & & & $\mathrm{X}$ & & $\mathrm{X}$ & & & $\mathrm{X}$ & & & & & $\mathrm{X}$ & & $\mathrm{X}$ & \\
\hline $\mathrm{N}$ & $\mathrm{X}$ & & & $\mathrm{X}$ & & & $\mathrm{X}$ & & $\mathrm{X}$ & & & & & $\mathrm{X}$ & & $\mathrm{X}$ & \\
\hline $\mathrm{O}$ & $\mathrm{X}$ & & & $\mathrm{X}$ & & & $\mathrm{X}$ & & $\mathrm{X}$ & & & $\mathrm{X}$ & & & & & $\mathrm{X}$ \\
\hline $\mathrm{P}$ & $\mathrm{X}$ & & & $\mathrm{X}$ & & & $\mathrm{X}$ & & $\mathrm{X}$ & & & & $\mathrm{X}$ & & & & $\mathrm{X}$ \\
\hline $\mathrm{Q}$ & $\mathrm{X}$ & & & $\mathrm{X}$ & & $\mathrm{X}$ & & & $\mathrm{X}$ & & & & & $\mathrm{X}$ & & & $\mathrm{X}$ \\
\hline $\mathrm{R}$ & & & $\mathrm{x}$ & & $\mathrm{X}$ & $\mathrm{X}$ & & & $\mathrm{X}$ & & & $\mathrm{X}$ & & & $\mathrm{X}$ & & \\
\hline $\mathrm{S}$ & & & $\mathrm{X}$ & & $\mathrm{X}$ & $\mathrm{X}$ & & & $\mathrm{X}$ & & & & $\mathrm{X}$ & & $\mathrm{X}$ & & \\
\hline $\mathrm{T}$ & & $\mathrm{X}$ & & & $\mathrm{X}$ & $\mathrm{X}$ & & & $\mathrm{X}$ & & & & & $\mathrm{X}$ & & $\mathrm{X}$ & \\
\hline $\mathrm{U}$ & & & $\mathrm{X}$ & & $\mathrm{X}$ & $\mathrm{X}$ & & & $\mathrm{X}$ & & & & & $\mathrm{X}$ & & $\mathrm{X}$ & \\
\hline $\mathrm{V}$ & & $\mathrm{X}$ & & & $\mathrm{X}$ & $\mathrm{X}$ & & & $\mathrm{X}$ & & & & & $\mathrm{X}$ & & & $\mathrm{X}$ \\
\hline $\mathrm{W}$ & & & $\mathrm{x}$ & & $\mathrm{X}$ & $\mathrm{X}$ & & & $\mathrm{X}$ & & & & & $\mathrm{X}$ & & & $\mathrm{X}$ \\
\hline $\mathrm{X}$ & & & $\mathrm{X}$ & & $\mathrm{X}$ & $\mathrm{X}$ & & & $\mathrm{X}$ & & & & & $\mathrm{X}$ & & & $\mathrm{X}$ \\
\hline Y & & $\mathrm{X}$ & & & $\mathrm{X}$ & & $\mathrm{X}$ & & $\mathrm{X}$ & & & & & $\mathrm{x}$ & & & $\mathrm{x}$ \\
\hline $\mathrm{Z}$ & & & $\mathrm{X}$ & & $\mathrm{X}$ & & $\mathrm{X}$ & & $\mathrm{X}$ & & & & & $\mathrm{X}$ & & & $\mathrm{x}$ \\
\hline
\end{tabular}

\section{Results and discussion}

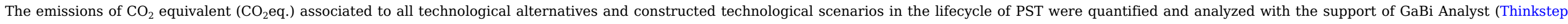

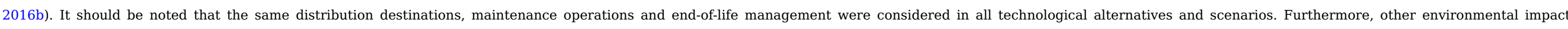

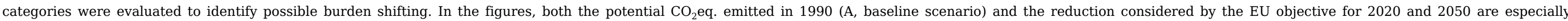
highlighted.

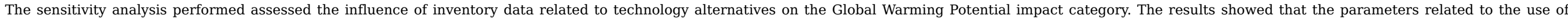

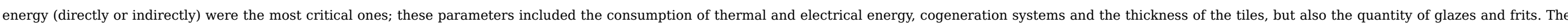




\subsection{Potential reduction by technological alternatives}

\subsubsection{Product design alternatives}

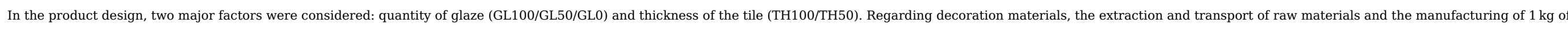

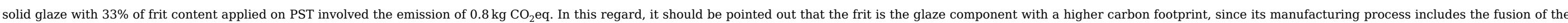
raw materials at around $1500^{\circ} \mathrm{C}$ (Gómez-Tena et al., 2009). Consequently, the reduction in the amount of glaze or frit content would entail an almost proportional reduction of $\mathrm{CO}_{2}$ eq. emissions.

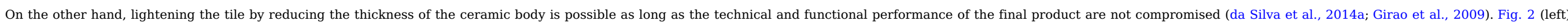

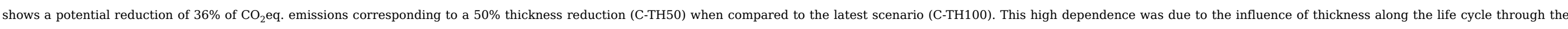

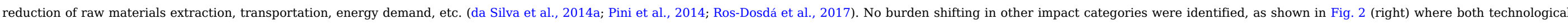

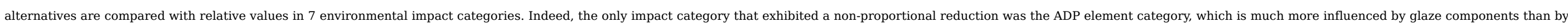
body thickness.

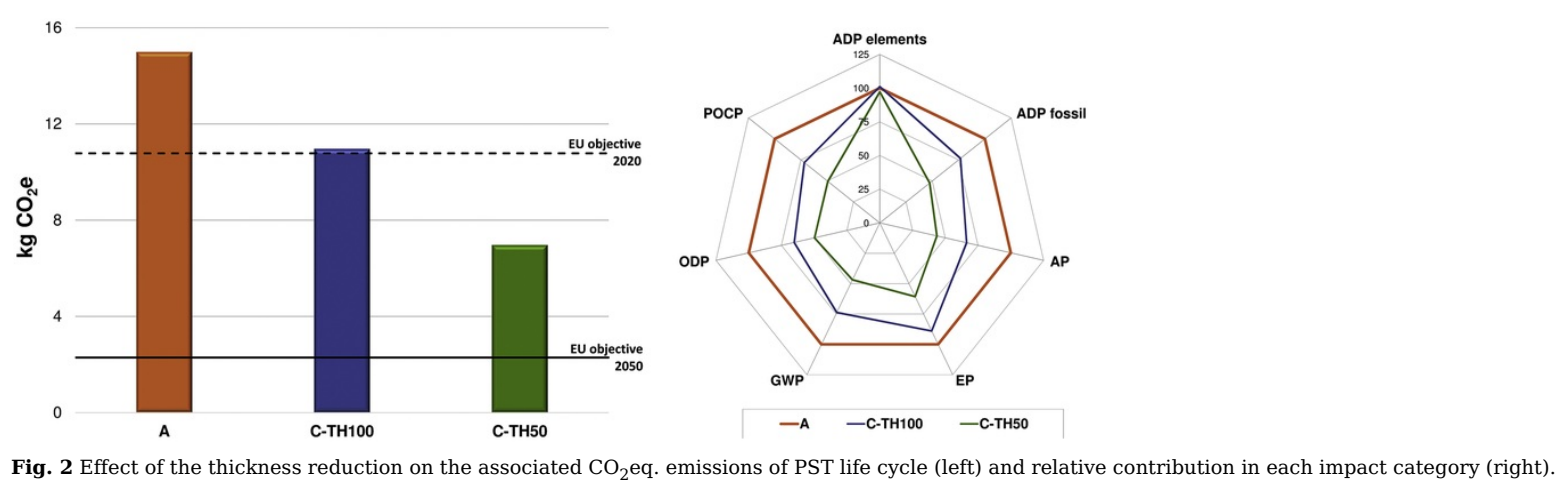

\section{alt-text: Fig. 2}

\subsubsection{Manufacturing process alternatives}

Two main process alternatives were analyzed: body raw materials preparation process (WCS/DRY) and energy efficiency technologies implemented in driers and kilns (CTT/WDS).

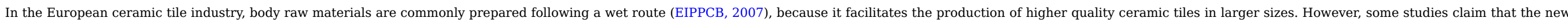

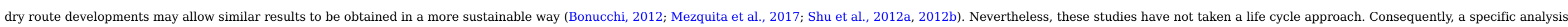
has been included in this work. To perform the comparison in this section, three alternatives were considered: wet route (WET); wet route using combined heat and power cogeneration systems (WCS); and dry route (DRY).

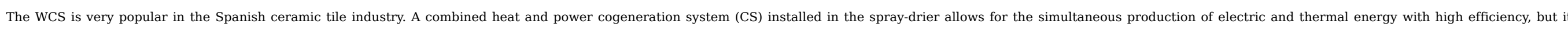

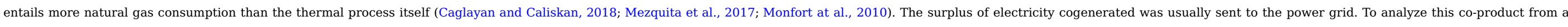

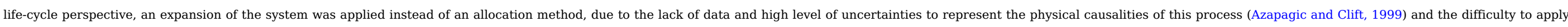
economic allocation since only the electricity which is sold to the grid has an economic value. Then, it was considered that only flexible technologies of the SGM would be displaced by the system (Weidema, 2000).

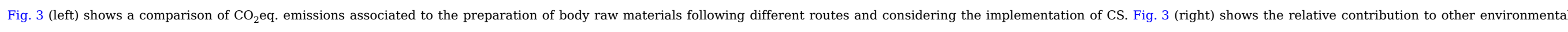

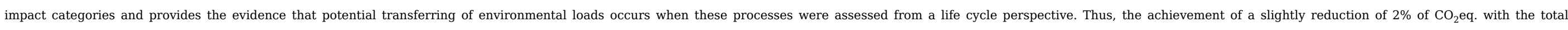
implementation of DRY milling instead of the WCS would imply increasing the emissions of acidification substances and photochemical oxidants by $9 \%$ and $12 \%$, respectively. 


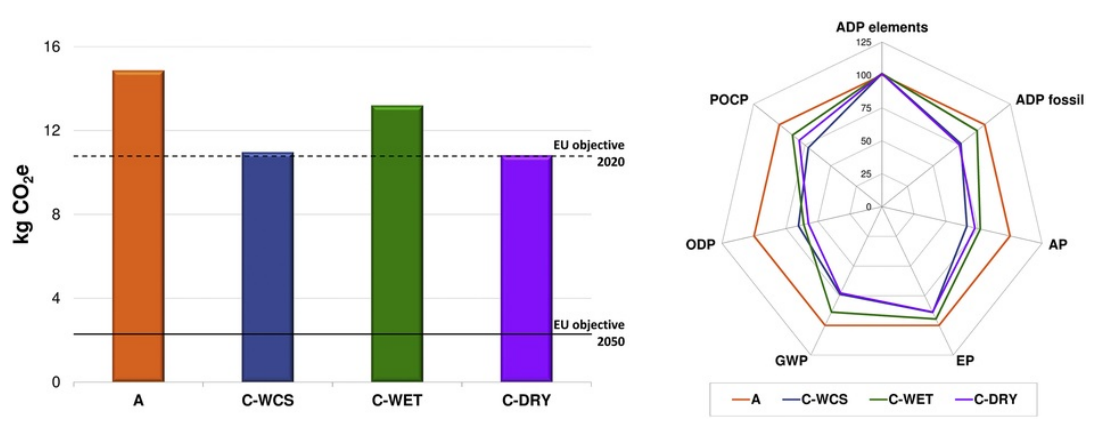

Fig. 3 Effect of the preparation of raw material on the associated $\mathrm{CO}_{2}$ eq. emissions of PST life cycle (left) and relative contribution in each impact category (right). alt-text: Fig. 3

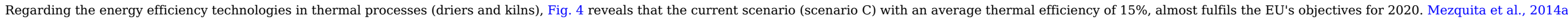

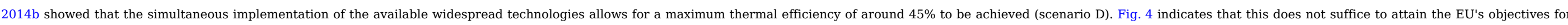
2050; therefore, these outcomes suggest that the combination of widespread and breakthrough technologies will be needed.

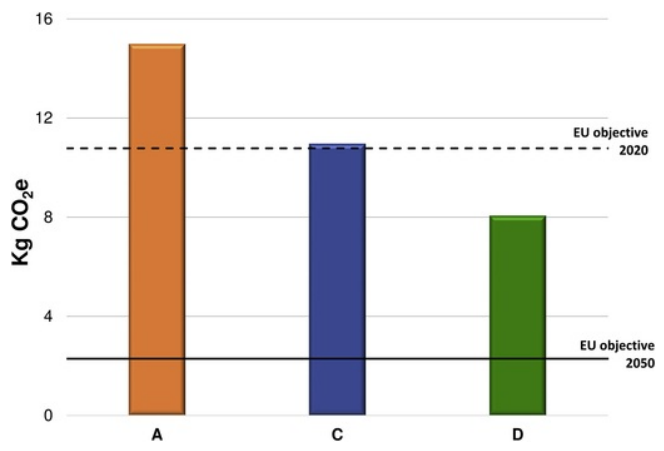

Fig. 4 Effect of the energy efficiency of thermal processes on the associated $\mathrm{CO}_{2}$ eq. emissions of PST life cycle.

\section{alt-text: Fig. 4}

\subsubsection{Energy source alternatives}

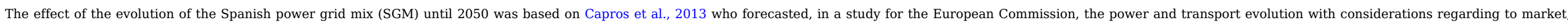

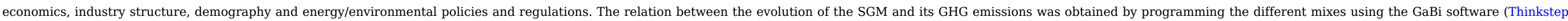
2016b).

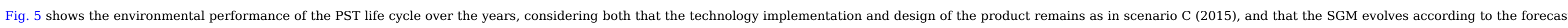

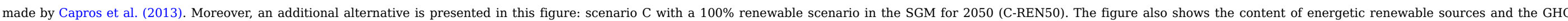

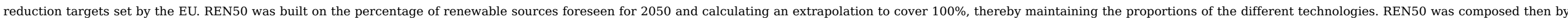
$54 \%$ wind power, $24 \%$ solar power, $15 \%$ hydropower, $6.5 \%$ biomass and $0.5 \%$ geothermal and other renewable energies. 


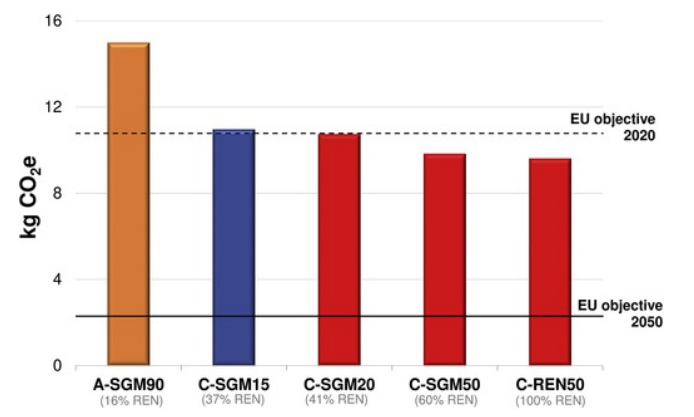

Fig. 5 Effect of the SGM on the associated $\mathrm{CO}_{2}$ eq. emissions of PST life cycle.

alt-text: Fig. 5

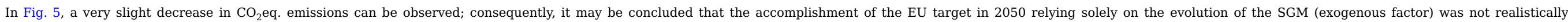
affordable, supporting Gabaldón-Estevan et al., 2016.

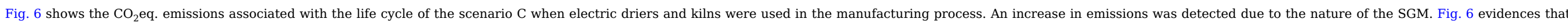

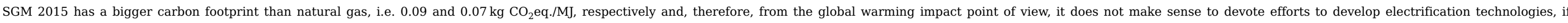

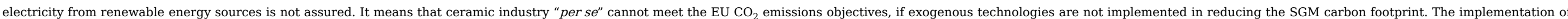
renewable sources at sector or plant scale does not seem to be sufficient to supply the required energy, hence this option has not been considered in this study.

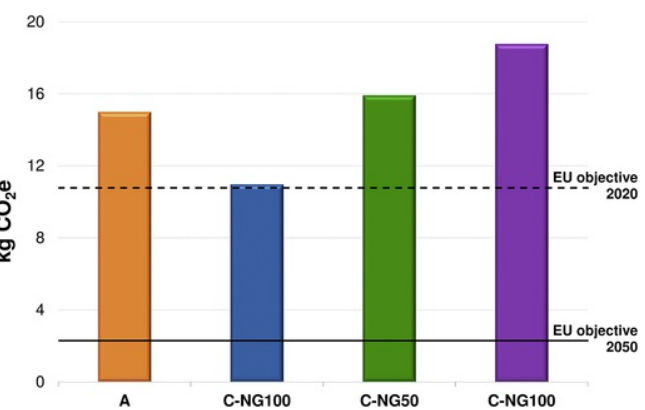

Fig. 6 Effect of the thermal process electrification on the associated $\mathrm{CO}_{2}$ eq. emissions of PST life cycle. alt-text: Fig. 6

\subsection{Potential reduction by technological scenarios}

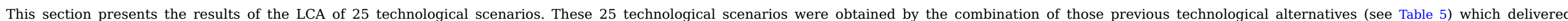
substantial improvements in reducing $\mathrm{CO}_{2}$ eq. emissions.

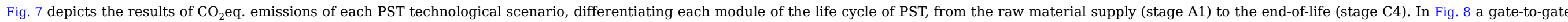
scope (life cycle stage A3) is shown. In each scope, the $\mathrm{CO}_{2}$ eq. emissions of the reference scenario and the correspondent EU objective reductions for 2020 and 2050 are marked 


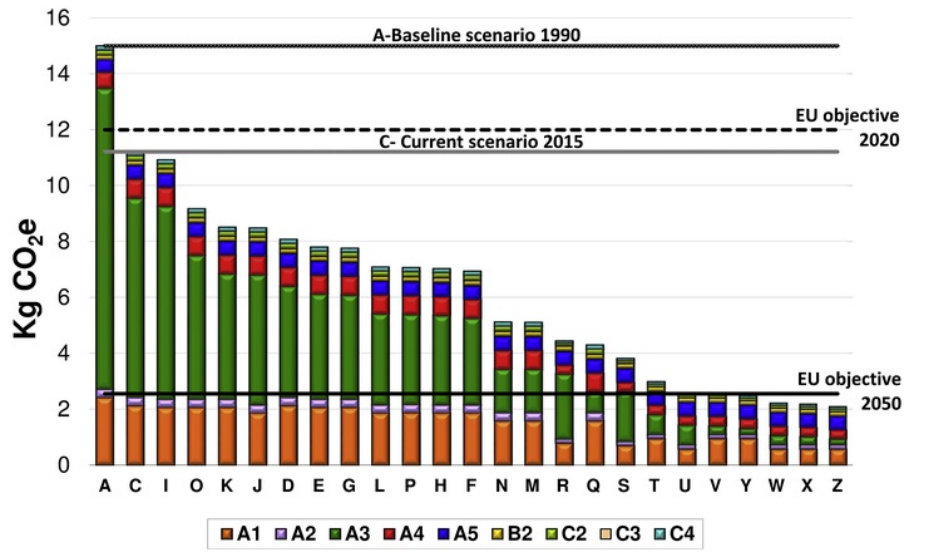

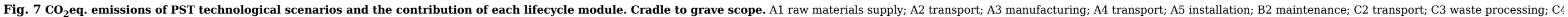
disposal. Codification used in EN 15804.

\section{alt-text: Fig. 7}

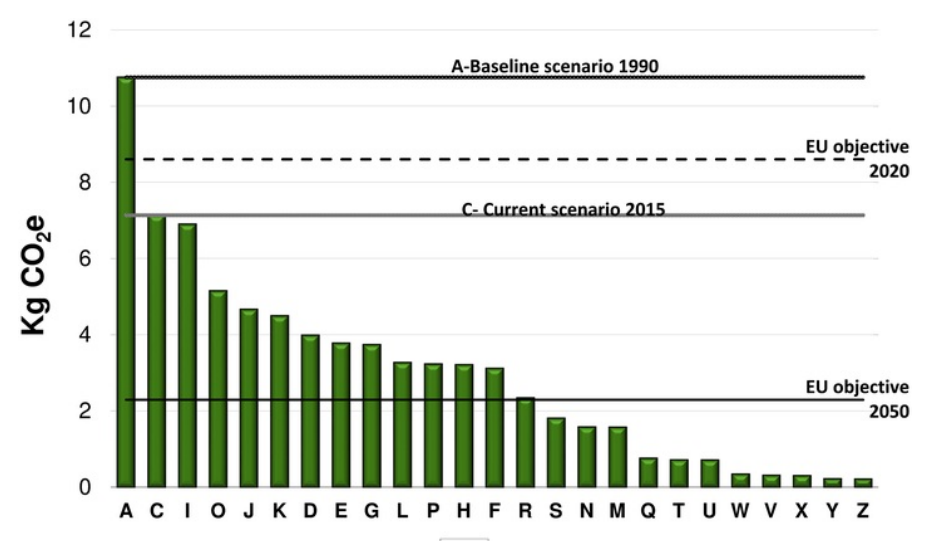

$\square$ A3

Fig. $8 \mathrm{CO}_{2}$ eq. emissions of PST technological scenarios with a gate to gate scope.

alt-text: Fig. 8

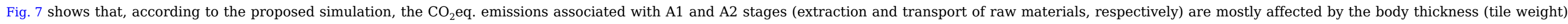

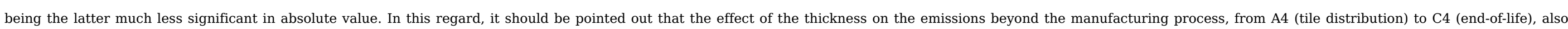

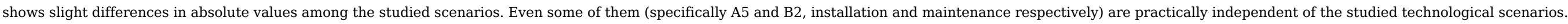

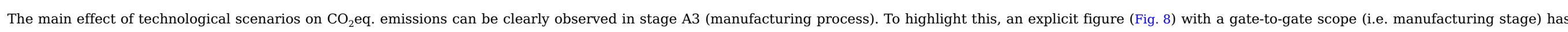
been produced.

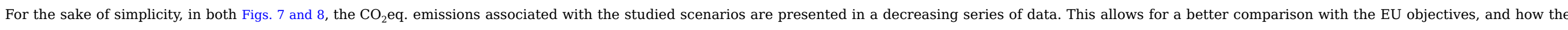

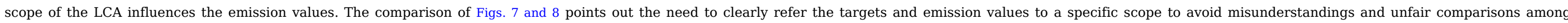
products and sectors. 


\subsubsection{Technological scenarios fulfilling EU's targets for 2020(Merge the paragraphs of this section 3.2.1 into a single paragraph)}

Figs. 7 and 8 clearly show that all the simulated technological scenarios fulfilled the EU 's targets for 2020, i.e. a $20 \%$ reduction in $\mathrm{CO}_{2}$ eq. emissions by 2020 compared to 1990 .

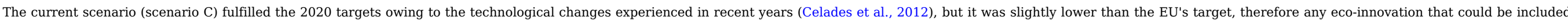
would ensure compliance with a greater margin.

The technological scenarios with an electric energy source defined for 2020 according to Capros et al. (2013)(Replace this reference: Capros et al. (2013) with "Capros et al., 2013) are the following ones: E; G; I; K; O; and R.

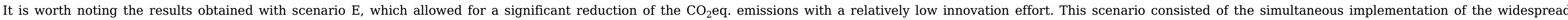
technologies in the drying and firing stages (increasing the thermal energy efficiency), while the rest of the alternatives remained unchanged.

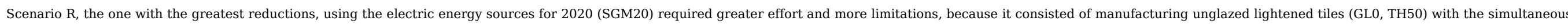
implementation of widespread technologies in the drying and firing stage (WDS), but it was really close to the EU 'targets for 2050, particularly when a gate-to-gate approach was applied.

\subsubsection{Technological scenarios fulfilling EU's targets for 2050}

Figs. 7 and 8 show that few simulated scenarios fulfilled the $\mathrm{EU}$ 's targets for 2050 , i.e. an $85 \%$ reduction in $\mathrm{CO}_{2}$ eq. emissions by 2050 compared to 1990 , especially when a cradle-to-grave approach was employed.

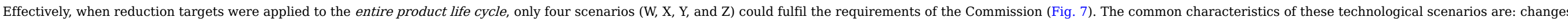

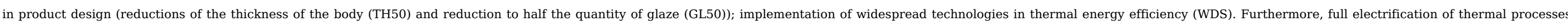

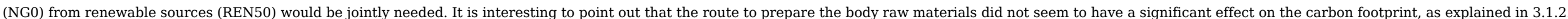

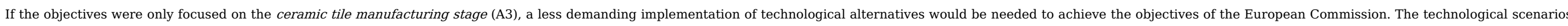

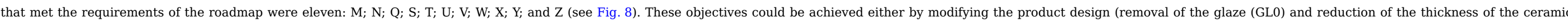
body (TH50)) or by electrifying 50\% of the thermal processes (NG50) through renewable sources (REN50). In all these cases, the implementation of widespread technologies in thermal energy efficiency (WDS) was considered.

\section{Conclusions}

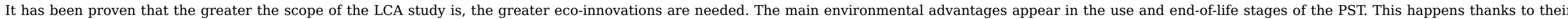

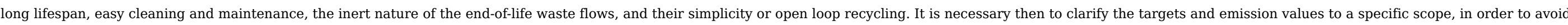
misunderstandings and unfair comparisons with products or sectors (wood floorings, carpets, etc.), which may have fewer production impacts but higher ones when it comes to use or disposal.

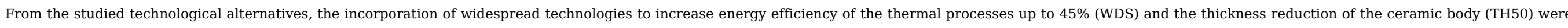

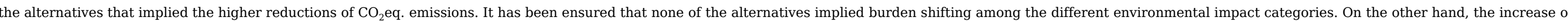
renewable energies in the SGM entailed relevant improvements.

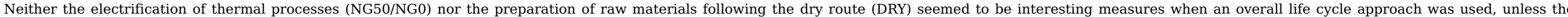
electric generation was dramatically decarbonized using renewable sources of energy, since the environmental burdens would shift to other categories and processes.

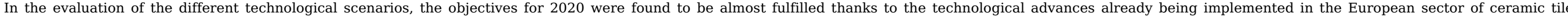

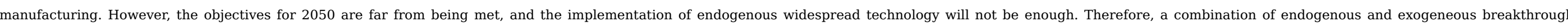

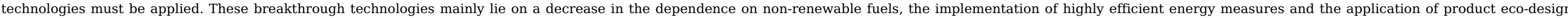
innovations.

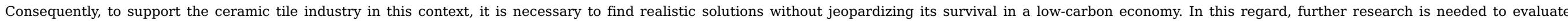

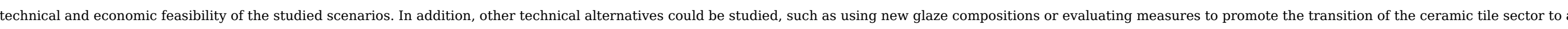
circular economy, among others. 


\section{Acknowledgements}

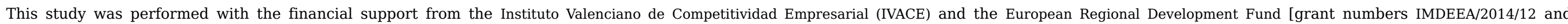
IMDEEA/2015/11] as well as from Climate KIC (Knowledge and Innovation Community) through the Pioneer into Practice Program [grant number AREP0047_2014-3.4-174_P062-01].

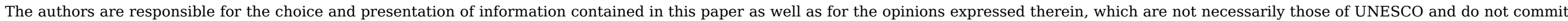
this Organization

\section{Appendix A. Supplementary data}

Supplementary data related to this article can be found at https://doi.org/10.1016/j.jclepro.2018.07.176.

\section{Uncited reference}

Cellura et al., 2011

\section{References}

Ajanovic A., Renewable fuels - a comparative assessment from economic, energetic and ecological point-of-view up to 2050 in EU-countries, Renew. Energy 60, 2013, 733-738 https://doi.org/10.1016/j.renene.2013.06.012.

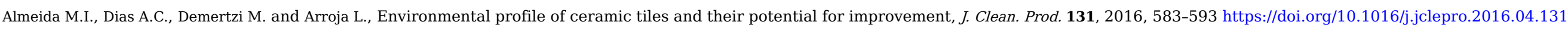

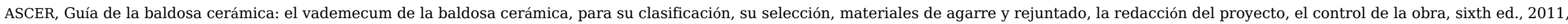
Generalitat Valenciana; Spain, Available: http://library.tileofspain.com/manuales-tecnicos/guia-de-la-baldosa-ceramica/\#8, Accessed 3 January 2018, (In Spanish).

Azapagic A. and Clift R., Allocation of environmental burdens in co-product systems: product-related burdens (Part 1), Int. J. Life Cycle Assess. 4, $1999,357$.

Baraldi L., World production and consumption of ceramic tiles, Ceram. world Rev. 123, 2017, 58-70, Available: https://issuu.com/tiledizioni/docs/cwr 123 , Accessed 11 May 2018.

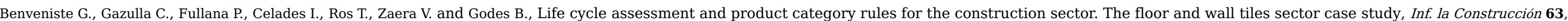
2011, 71-81 https://doi.org/10.3989/ic.10.034.

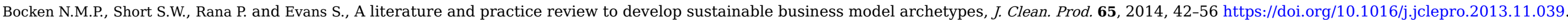
Bonucchi R., Dry preparation: quality and care for the environment, Ceramic World Review 22, 2012, 86-89.

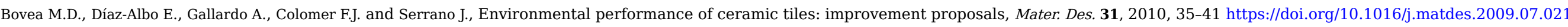

Caglayan H. and Caliskan H., Energy, exergy and sustainability assessments of a cogeneration system for ceramic industry, Appl. Therm. Eng. 136, 2018, 504-515

https://doi.org/https://doi.org/10.1016/j.applthermaleng.2018.02.064.

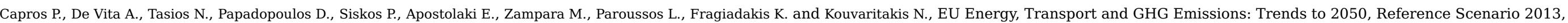
2013, European Commission Directorate-General for Energy, Directorate-General for Climate Action and Directorate-General for Mobility and Transport; Luxembourg https://doi.org/10.2833/17897.

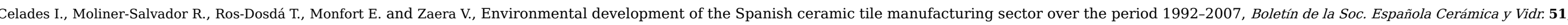
2012, 111-118 https://doi.org/10.3989/cyv.162012.

Cellura M., Longo S. and Mistretta M., Sensitivity analysis to quantify uncertainty in Life Cycle Assessment: the case study of an Italian tile, Renew. Sustain. Energy Rev. 15, 2011, 4697-4705

https://doi.org/https://doi.org/10.1016/j.rser.2011.07.082. 


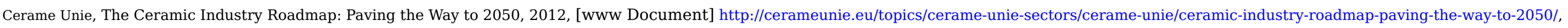
Accessed 3 January 2018.

Cerame Unie, Statistics, Figures and Facts, 2017, [www Document] http://cerameunie.eu/ceramic-industry/facts-figures/, Accessed 11 May 2018.

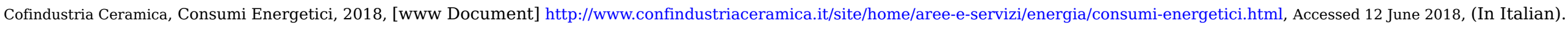

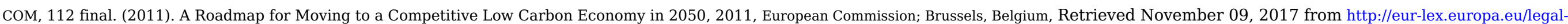
content/EN/ALL/?uri=CELEX:52011DC0112.

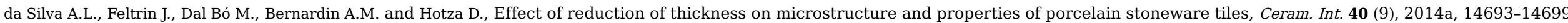
https://doi.org/10.1016/j.ceramint.2014.05.150.

da Silva A.L., Bernardin A.M. and Hotza D., Forming of thin porcelain tiles: a comparison between tape casting and dry pressing, Ceram. Int. 40 (2), 2014b, 3761-3767 https://doi.org/https://doi.org/10.1016/j.ceramint.2013.09.044.

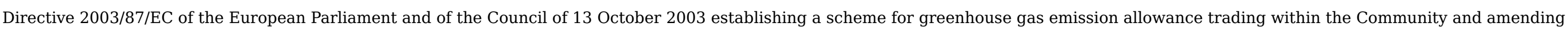
Council Directive 96/61/EC. L 275/32, 25.10.2003. Retrieved November 09, 2017 from http://eur-lex.europa.eu/legal-content/EN/TXT/PDF/?uri=CELEX:32003L0087\&from=EN.

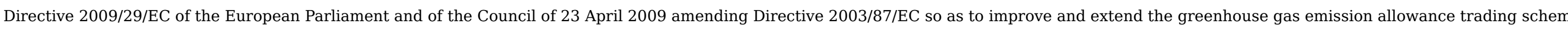
of the Community. L 140/63, 05.06.2009. Retrieved November 09, 2017 from https://doi.org/10.3000/17252555.L 2009.140.eng.

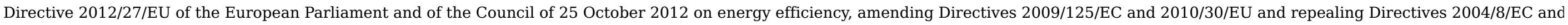
2006/32/EC. L 315/1, 14.11.2012. Retrieved November 09, 2017 from https://doi.org/10.3000/19770677.L_2012.315.eng.

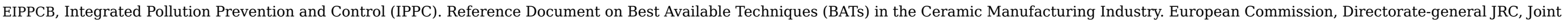
Research Centre, 2007, Institute for Prospective Technological Studies (Sevilla). Technologies for Sustainable Development. European IPPC Bureau.

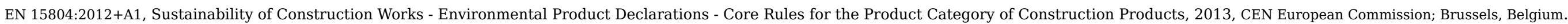

Gabaldón-Estevan D., Criado E. and Monfort E., The green factor in European manufacturing: a case study of the Spanish ceramic tile industry, J. Clean. Prod. 70, 2014, 242-250 https://doi.org/10.1016/j.jclepro.2014.02.018.

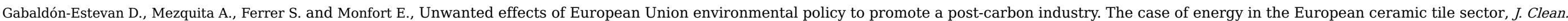
Prod. 117, 2016, 41-49 https://doi.org/10.1016/j.jclepro.2016.01.021.

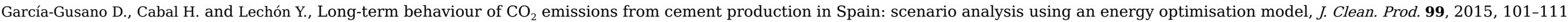
https://doi.org/10.1016/j.jclepro.2015.03.027.

Girao J., Amaro N., Carvalho J. and Piquer J., Decreased thickness porcelain tiles. Revigres Light, Boletín la Soc. Española Cerámica y Vidr. 48 (2), 2009 , 99-101, (In Spanish).

Gómez-Tena M.P., Bou E., Moreno A., Cook S. and Galindo M., Fritless glaze compositions for single fast fired tiles, Interceram. Int. Ceram. Rev. 58, 2009 , 78-84.

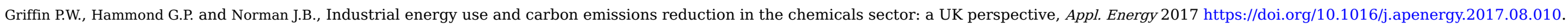

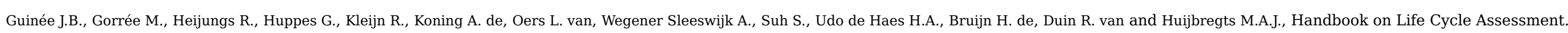
Operational Guide to the ISO Standards. I: LCA in Perspective. IIa: Guide. IIb: Operational Annex. III: Scientific Background, 2002, Kluwer Academic Publishers; Dordrecht.

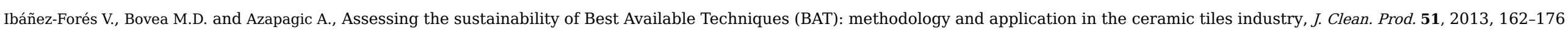


https://doi.org/10.1016/j.jclepro.2013.01.020.

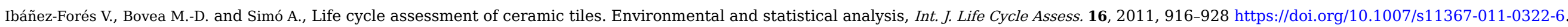

ISO 14040, Environmental Management -- Life Cycle Assessment -- Principles and Framework, second ed., 2006, International Organization for Standardization; Geneva.

ISO 14044, Environmental Management -- Life Cycle Assessment -- Requirements and Guidelines, 2006, International Organization for Standardization; Geneva.

JRC-IES Joint Research Centre, I. for E. and S, European Reference Life-cycle Database, 2015 http://eplca.jrc.ec.europa.eu/ELCD3/processList.xhtml, 3.2, Accessed 16 May 2016.

Klöpffer W. and Grahl B., Ökobilanz (lca): Ein leitfaden für ausbildung und beruf, 2009, John Wiley \& Sons, (In German).

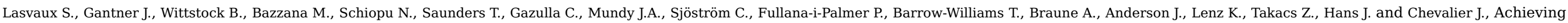

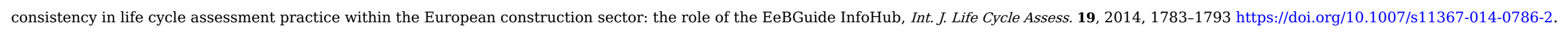
Melchiades F.G., Daros M.T. and Boschi A.O., Porcelain tiles by the dry route, Boletín la Soc. Española Cerámica y Vidr. 49 (4), 2010, 221-226, (In Spanish).

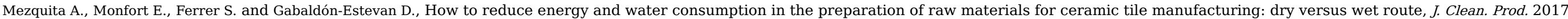
https://doi.org/10.1016/j.jclepro.2017.04.082.

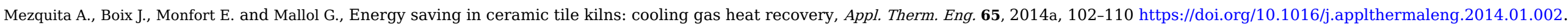

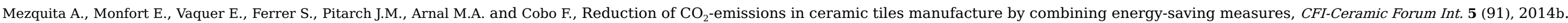

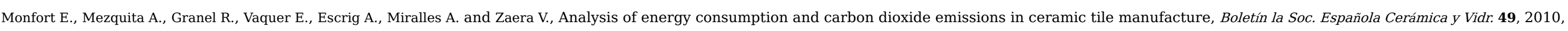

303-310, Available: http://boletines.secv.es/upload/20100901173134.201049303.pdfdioma=SPA, Accessed 3 January 2018, (In Spanish).

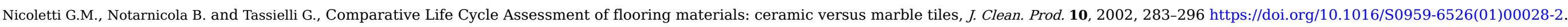

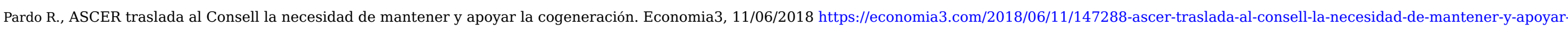

la-cogeneracion/, Accessed 12 June 2018, (In Spanish).

PE International, Database for Life Cycle Engineering, Copyright, TM. 1992-2008 (Compilation. 4.4.142.1, DB Version 4.131), 2008a.

PE International, GaBi Software-system. Compilation 4.131, 2008b http://www.gabi-software.com/software/gabi-4/, Accessed 16 May 2017.

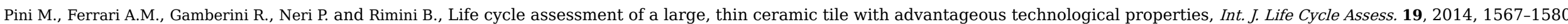

https://doi.org/10.1007/s11367-014-0764-8.

Raimondo M., Processing and properties of large-sized ceramic slabs, Boletín la Soc. Española Cerámica y Vidr. 49, 2010, $289-295$.

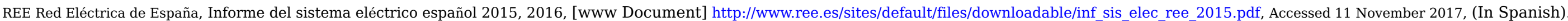

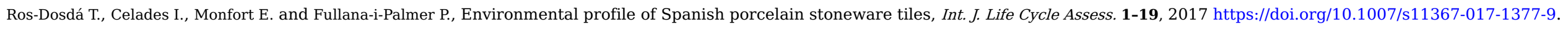

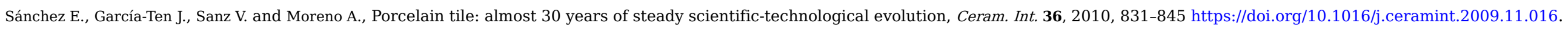

Schianchi S., Quality in low-consumption granulation, Ceram. world Rev. 2012, 116-118.

Selvakkumaran S., Limmeechokchai B., Masui T., Hanaoka T. and Matsuoka Y., Low carbon society scenario 2050 in Thai industrial sector, Energy Convers. Manag. 85, 2014, 663-674

https://doi.org/10.1016/j.enconman.2014.03.040. 
Shu Z., Garcia-Ten J., Monfort E., Amoros J.L., Zhou J. and Wang Y.X., Cleaner production of porcelain tile powders. Fired compact properties, Ceram. Int. 38, 2012a, 1479-1487 https://doi.org/10.1016/j.ceramint.2011.09.031.

Shu Z., Garcia-Ten J., Monfort E., Amorós J.L., Zhou J. and Wang Y.X., Cleaner production of porcelain tile powders. Granule and green compact characterization, Ceram. Int. 38, 2012b, 517-526 https://doi.org/10.1016/j.ceramint.2011.07.037.

Streimikiene D. and Šivickas G., The EU sustainable energy policy indicators framework, Environ. Int. 34, 2008, 1227-1240 https://doi.org/10.1016/j.envint.2008.04.008.

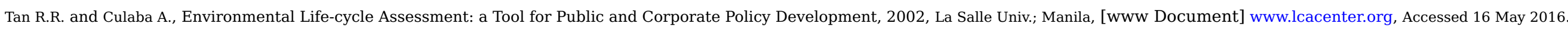

Thinkstep, Database for Life Cycle Engineering, Copyrignt Thinkstep AG. 1992-2016 (Compilation 7.2.2.28, DB Version 6.115), 2016a.

Thinkstep, GaBi Software-system. Compilation 7.2.2.28, 2016b http://www.gabi-software.com/software/, Accessed 17 May 2016.

Weidema B., Avoiding co-product allocation in life-cycle assessment, J. Ind. Ecol. 4, 2000, 11-33 https://doi.org/10.1162/108819800300106366.

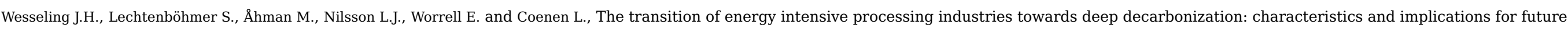
research, Renew. Sustain. Energy Rev. 79, 2017, 1303-1313 https://doi.org/10.1016/j.rser.2017.05.156.

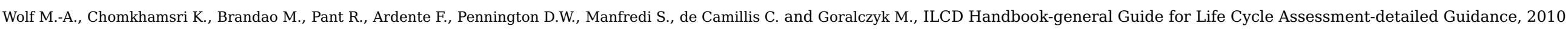
https://doi.org/10.2788/38479.

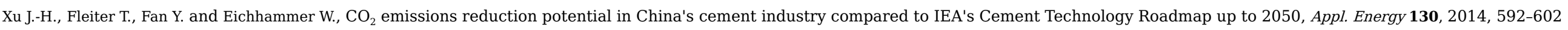
https://doi.org/10.1016/j.apenergy.2014.03.004.

\section{Appendix A. Supplementary data}

Supplementary material associated with this article can be found in the online version:

- Sensitivity analysis

- List of abbreviations

The following are the supplementary data related to this article:

Multimedia Component 1

Multimedia component 1

alt-text: Multimedia component 1

Multimedia Component 2

Multimedia component 2

alt-text: Multimedia component 2

Highlights

- EU $2020 \mathrm{CO}_{2}$ reduction target for the ceramic tile industry can be met through current technologies.

- The ceramic tile industry will not meet $\mathrm{EU} \mathrm{CO}_{2}$ reduction target for 2050 unless they combine several measures along the life cycle. 


\section{Queries and Answers}

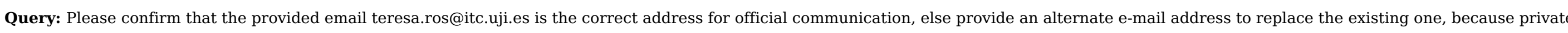
e-mail addresses should not be used in articles as the address for communication.

Answer: trosdosda@gmail.com

Query: Please check the address for the corresponding author that has been added here, and correct if necessary.

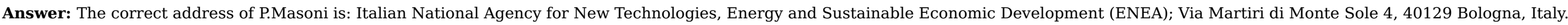
Presently, Ecoinnovazione srl; via D’Azeglio 52, 40123 Bologna, Italy

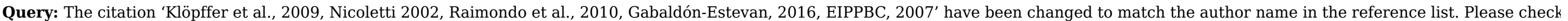
here and in subsequent occurrences, and correct if necessary.

\section{Answer: ok}

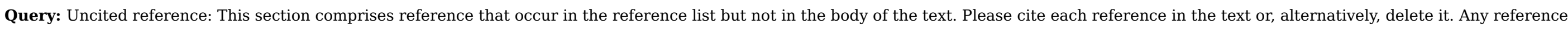
not dealt with will be retained in this section.

Answer: Cellura et al., is only cited in the supplementary material 2 and not cited in the manuscript.

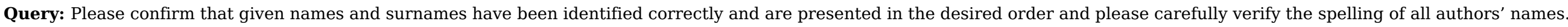
Answer: Names and Surnames are correct

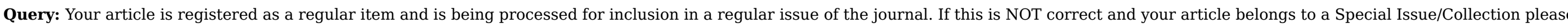
contact k.kumar.1@elsevier.com immediately prior to returning your corrections.

Answer: This Article can be registered and processed as a regular issue of the journal 